\title{
Erythroidine Alkaloids: A Novel Class of Phytoestrogens
}

Authors

Affiliations
Sefirin Djiogue ${ }^{1,2,3}$, Maria Halabalaki ${ }^{1}$, Dieudonné Njamen ${ }^{3}$, Georg Kretzschmar ${ }^{2}$, George Lambrinidis ${ }^{4}$, Josephine Hoepping ${ }^{2}$, Francesca M. Raffaelli ${ }^{2}$, Emmanuel Mikros ${ }^{4}$, Alexios-Leandros Skaltsounis ${ }^{1}$, Günter Vollmer ${ }^{2}$

The affiliations are listed at the end of the article
Key words

- Erythrina poeppigiana

- Fabaceae

- erythroidines

- alkaloids

- phytoestrogens

- reporter gene assay

received March 27, 2013

revised June 11, 2014

accepted June 14, 2014

Bibliography

DOI http://dx.doi.org/

10.1055/s-0034-1382861

Planta Med 2014; 80: 861-869

(c) Georg Thieme Verlag KG

Stuttgart · New York .

ISSN 0032-0943

\section{Correspondence}

Prof. Dr. Günter Vollmer

Technische Universität Dresden

Molecular Cell Physiology \&

Endocrinology

Helmholtzstr. 10

01069 Dresden

Germany

Phone: + 4935146331922

Fax: + 4935146331923

Guenter.Vollmer@

tu-dresden.de

\section{Correspondence}

\section{Dr. Sefirin Djiogue}

Laboratory of Animal Physiology Department of Animal Biology

and Physiology

Faculty of Science

University of Yaounde 1

P. O. Box 812

Yaounde

Cameroon

Phone: + 23778585770

sefirin.djiogue@ymail.com

\section{Abstract}

$\nabla$

Erythrina poeppigiana is a medicinal plant which is widely used in Asia, Latin America, and Africa in traditional remedies for gynecological complications and maladies. In continuation of studies for the discovery of novel phytoestrogens, four erythroidine alkaloids, namely $\alpha$-erythroidine, $\beta$ erythroidine, and their oxo-derivatives 8 -oxo- $\alpha$ erythroidine and 8-oxo- $\beta$-erythroidine, were isolated and structurally characterized from the methanolic extract of the stem bark of E. poeppigiana. Due to the high amounts of erythroidines in the extract and considering the widespread utilization of Erythrina preparations in traditional medicine, the exploration of their estrogenic properties was performed. The estrogenicity of the isolated erythroidines was assayed in various estrogen receptor-(ER)-dependent test systems, including receptor binding affinity, cell culture based ER-dependent reporter gene assays, and gene expression studies in cultured cells using reverse transcription polymerase chain reaction techniques. $\alpha$-Erythroidine and $\beta$-erythroidine

\section{Introduction}

\section{$\nabla$}

Medicinal plants used in traditional medicine can be considered as an almost permanent source of medication of significant importance. A high percentage of individuals, particularly in third world countries, depend on medicinal plant-based preparations for their primary health care. In particular, about $80 \%$ of the population in developing countries still resorts to medicinal plants for various reasons. Most important, they are affordable and, according to their long-term use in humans, they are usually considered to be safe, although their consumption may pose risks undetected so far $[1,2]$. Unfortunately, very often the knowledge base for traditional use is empirical. More impor- showed binding affinity values for ER $\alpha$ of $0.015 \pm 0.010 \%$ and $0.005 \pm 0.010 \%$, respectively, whereas only $\beta$-erythroidine bound to ER $\beta$ $(0.006 \pm 0.010 \%)$. In reporter gene assays, both erythroidines exhibited a significant dose-dependent estrogenic stimulation of ER-dependent reporter gene activity in osteosarcoma cells detectable already at $10 \mathrm{nM}$. Results were confirmed in the MVLN cells, a bioluminescent variant of MCF7 breast cancer cells. Further, $\alpha$-erythroidine and $\beta$-erythroidine both induced the enhanced expression of the specific ER $\alpha$-dependent genes trefoil factor-1 and serum/glucocorticoid regulated kinase 3 in MCF-7 cells, confirming estrogenicity. Additionally, using molecular docking simulations, a potential mode of binding on $\mathrm{ER} \alpha$, is proposed, supporting the experimental evidences. This is the first time that an estrogenic profile is reported for erythroidine alkaloids, potentially a new class of phytoestrogens.

Supporting information available online at http://www.thieme-connect.de/products

tantly, it is usually not known whether the plants or plant-derived products contain bioactive compounds, which may account for the traditional use.

Among these traditional medicinal plants, Erythrina poeppigiana, from the Erythrina species (Fabaceae), is of particular interest since it is widely used for the treatment of various disorders and complications including hormone-related conditions $[3,4]$. It is distributed and utilized in traditional remedies in South America, Africa, and Asia. Irrespective of the geographical site of use, this plant has been reported as being used in the folk empirical system of medicine as an abortive agent and for the treatment of amenorrhea, microbial infections, jaundice, agitation, and insom- 


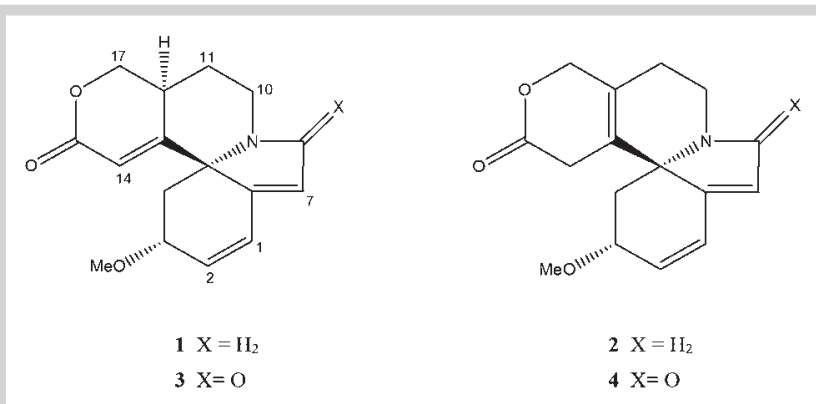

Fig. 1 Chemical structures of isolated compounds 1 ( $\alpha$-erythroidine), 2 ( $\beta$-erythrodine), 3 (8-oxo- $\alpha$-erythrodine), and $\mathbf{4}$ (8-oxo- $\beta$-erythrodine) on MVLN cells (breast cancer cell line derivative).

nia [5]. E. poeppigiana is particularly rich in secondary metabolites with estrogen-like activities commonly referred to as phytoestrogens [6]. In a recent study, the dichloromethane extract of $E$. poeppigiana was found to be exceptionally rich in isoflavones, among them eight specifically prenylated genistein derivatives of which seven exhibited significant estrogenic activities in vitro $[6,7]$.

Chemically speaking, the large majority of the newly discovered phytoestrogens belongs either to flavonoids (flavones, flavanones, chalchones), isoflavonoids (isoflavones, coumestanes, arylbenzofurans), or lignans, with isoflavones being the best characterized class [8]. Reports on plant secondary metabolites for which the estrogenic activity originates from an alkaloid structure are rather scarce. A study published in 1994 by Ng et al. reported for the first time estrogenic activity of an alkaloid. Yuehchukene, a bis-indole alkaloid isolated from Murraya paniculata (Rutaceae), exhibited mixed estrogenic and antiestrogenic properties in vivo and in vitro [9]. In 2001, Nazrullaev et al. reported the estrogenic activity of several quinoline alkaloids [10]. Recently, Allred et al. described the estrogenic activity of trigonelline, an alkaloid from coffee beans structurally related to vitamin B3 [11]. A possible reason for alkaloids being neglected towards the exploration of their estrogenicity could be that they are generally considered toxic. However, the striking structural variation of a vast number of natural alkaloids is the basis of a wide spectrum of quite diverse activities. Moreover, several pharmacological studies have shown that several alkaloids belonging to different chemical subgroups exhibit only a low toxicity [12, 13].

Along these lines and in a continuing effort to characterize the chemical and biological properties of medicinal plants traditionally used for the treatment of gynecological problems, we investigated the methanolic extract of $E$. poeppigiana. The alkaloidrich fraction was targeted and isolated, and the corresponding constituents were purified and structurally elucidated using chromatographic and spectroscopic methods, respectively. Moreover, various estrogen receptor (ER)-dependent test systems, including receptor binding and reporter gene assays, in two independent cellular systems, namely MVLN breast cancer cells (a bioluminescent variant of MCF-7 breast cancer cells) [14] and U2OS human osteosarcoma cells [15], were used. These cell lines were utilized for determination of potential estrogen-like activities of the isolated alkaloids. We finally evaluated the impact of the most potent constituents of the methanolic extract of E. poeppigiana on the expression of the endogenous estrogen regulated genes SGK3 (serum/glucocorticoid regulated kinase 3) and trefoil factor-1 (TFF1) in MCF-7 cells. In addition, to further substantiate observed estrogenic activities of $\alpha$ - and $\beta$-erythroidine in silico, docking calculations were performed. The interactions of isolated erythroidines to the ligand binding domain (LBD) of the estrogen receptor alpha (ER $\alpha$ ) have been studied considering ER plasticity as expressed by different conformational preferences derived by crystallography.

\section{Results}

$\nabla$

The relative binding affinities (RBA) to $E R \alpha$ and $E R \beta$ for 1-4 ( $\bullet$ Fig. 1) were determined using purified recombinant proteins and a fluorescence polarization approach ( Table 1 and Fig. 1S, Supporting Information). Compounds $\mathbf{1}$ and $\mathbf{2}$ displayed RBA values for ER $\alpha$ of $0.015 \pm 0.010$ and $0.005 \pm 0.010$, respectively. For 3 and 4 at the concentrations tested, no dose-dependent competition curve could be obtained. Therefore, no RBA could be determined, implying a very low or no affinity for ER $\alpha$. The same holds for binding to ER $\beta$, except for $\mathbf{2}$, for which a relatively low RBA of $0.006 \pm 0.010$ to $E R \beta$ could be determined. IC $_{50}$ values of estradiol, $\mathbf{1}$, and 2 for ER $\alpha$ were $8.31 \times 10^{-9} \mathrm{M}, 5.73 \times 10^{-5} \mathrm{M}$, and $1.11 \times 10$

${ }^{-4} \mathrm{M}$, respectively, whereas the $\mathrm{IC}_{50}$ of 2 to $\mathrm{ER} \beta$ was $9.61 \times 10^{-5} \mathrm{M}$ as compared to $5.47 \times 10^{-9} \mathrm{M}$ for estradiol.

To verify whether this binding affinity to the ER translates into receptor transactivation, we performed reporter gene assays. As toxicity of alkaloids is a concern, we additionally performed the MTT cytotoxicity assay in U2OS osteosarcoma cells. This test showed that both erythroidines are void of cytotoxicity in doses up to $10 \mu \mathrm{M}$ (Fig. 13S, Supporting Information).

Estrogenic activity of the alkaloids was first assayed in a derivative of ER-positive MCF-7 breast cancer cells (MVLN). In accordance with the aim of our study, we assessed the estrogenic activity of the four isolated alkaloids as well as a positive (E2 $10 \mathrm{nM}$ ) and a negative (DMSO 0.1\%) control in MVLN cells, and verified observations for the most potent molecules in U2OS human osteosarcoma cells. Compound 1 induced significant and dose-dependent luciferase reporter gene activity in MVLN cells, starting from $10 \mathrm{nM}$, while compound $\mathbf{2}$ induced significant estrogenic

\begin{tabular}{|c|c|c|c|c|}
\hline & \multicolumn{2}{|l|}{ RBA (\%) } & \multicolumn{2}{|c|}{$I C_{50}(\mu \mathrm{M})$} \\
\hline & Ero & ER $\beta$ & Ero & ER $\beta$ \\
\hline Estradiol & 100 & 100 & 0.0083 & 0.0055 \\
\hline$\alpha$-Erythroidin & $0.015 \pm 0.010$ & n.m. & 57.3 & n.m. \\
\hline$\beta$-Erythroidin & $0.005 \pm 0.010$ & $0.006 \pm 0.010$ & 111 & 96.1 \\
\hline 8-Oxo- $\alpha$-erythroidin & n. m. & n.m. & n.m. & n.m. \\
\hline 8-Oxo- $\beta$-erythroidin & n.m. & n.m. & n.m. & n.m. \\
\hline
\end{tabular}

Table 1 Ligand binding data.

* n. m. = not measurable 

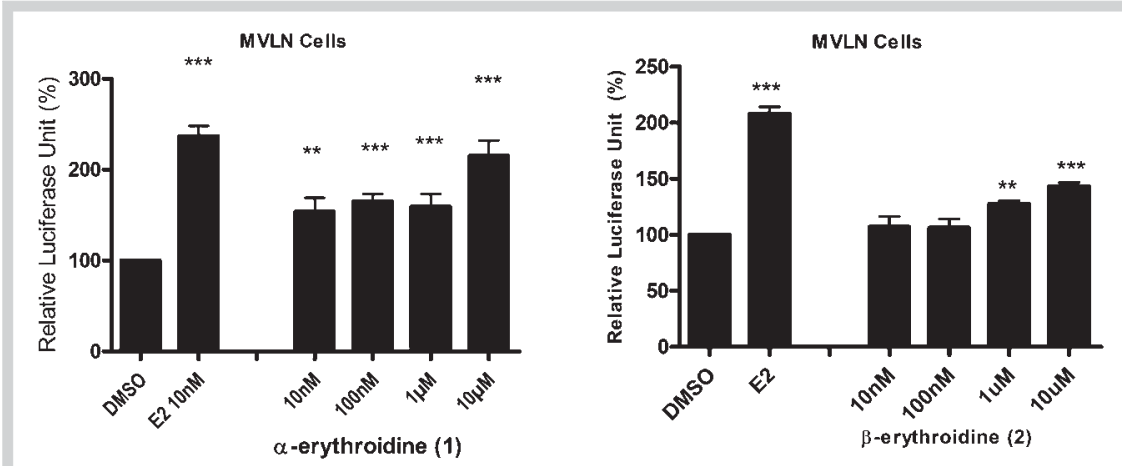

Fig. 2 Estrogenic activity of erythroidines $\mathbf{1}$ and $\mathbf{2}$ activated ER $\alpha$-dependent reporter gene expression in a statistically significant manner, reaching a maximum response at $10 \mu \mathrm{M}$, while $\mathbf{3}$ and $\mathbf{4}$ had no effects. Significance was calculated against DMSO (set to $100 \%$ ): ${ }^{* *} p<0.01,{ }^{* * *} p<0.001$. Data represent the mean \pm SD of at least three independent triplicate experiments. MVLN cells: breast cancer cell line derivative.
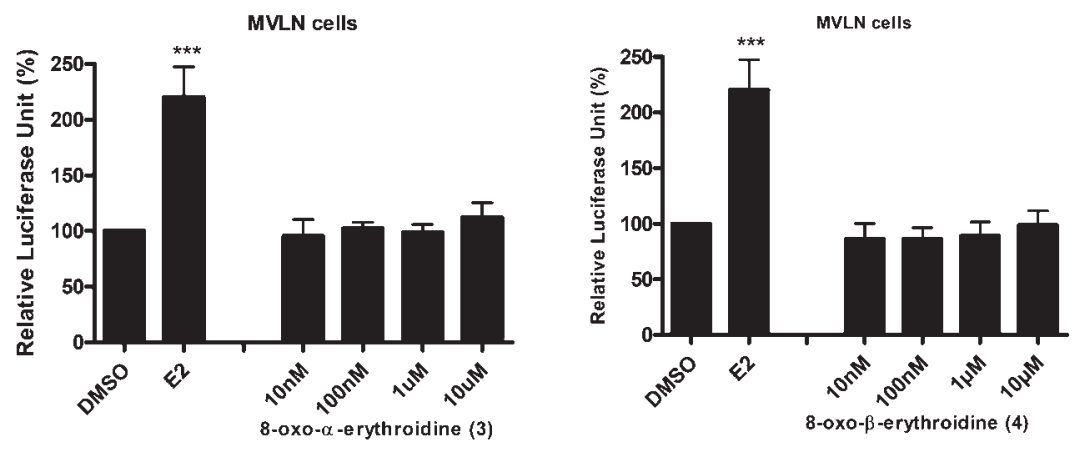

activity starting from $1 \mu \mathrm{M}$ ( $\odot$ Fig. 2 ). On the other hand, compounds 3 and 4, which are the corresponding 8-oxo derivatives of 1 and 2, failed to induce any significant estrogenic activity in MVLN cells ( Fig. 2). From these results, we made two decisions for additional experiments. First, only $\mathbf{1}$ and $\mathbf{2}$ exhibited sufficient activity to be studied in depth. Second, we decided to continue to investigate interactions of erythroidines with ER $\alpha$ only to address the issue of structure-function relationships.

As a consequence of this decision, compounds $\mathbf{1}$ and $\mathbf{2}$ have been investigated for their estrogenic potential in a cell line of a different organ, namely, bone-derived U2OS human osteosarcoma cells expressing ER $\alpha$ (U2OS-ER $\alpha$ ). Compound 1 induced significant and dose-dependent reporter gene activity in U2OS cells starting from $10 \mathrm{nM}$ ( Fig. 3), while 2 also induced a significant and dose-dependent activation of luciferase reporter gene activity in U2OS-ER $\alpha$ cells starting from $10 \mathrm{nM}$ ( Fig. 3). As a general observation, the maximum induction in response to compound 2 is by far less pronounced than that of compound 1 .

In order to verify whether the activation of the reporter gene activity by 1 and $\mathbf{2}$ is mediated through the ER, U2OS-ER $\alpha$ cells were coincubated with the higher effective dose of $\mathbf{1}$ and $\mathbf{2}$, and the pure antiestrogen Fulvestrant. Fulvestrant completely inhibited the induction of the reporter gene transcription by these alkaloids, indicating that their effect is ER-dependent ( $\mathrm{Fig} .4$ ).

Aiming to further characterize the estrogenicity of these alkaloids, we investigated whether the erythroidines are also capable of inducing endogenous target genes in MCF-7 breast cancer cells. The impact of $\mathbf{1}$ and $\mathbf{2}$ on the expression of the estrogen-regulated genes TFF1 ( Fig. 5 A and B) and serum and glucocorticoid-inducible kinase 3 (SGK3; 8 Fig. 5C and D) was evaluated in MCF-7 breast cancer cells. The expression of both genes was upregulated in response to $10^{-8} \mathrm{M}$ of estradiol and to $10^{-5} \mathrm{M}$ concentrations of both test substances ( $\bullet$ Fig.5). This effect was completely inhibited by coincubation with the antiestrogen fulvestrant (data not shown).

According to the chemical structure of erythroidines, their affinity for the ER was not expected. Most molecules showing strong estrogenic activity usually possess two $\mathrm{OH}$ groups in a distance of 10-12 Å. However compounds, both natural and semisynthetic, possessing only one $\mathrm{OH}$ group has showed a significant affinity to the ER [16]. Likewise, compounds 1 and 2, although they lack $\mathrm{OH}$ groups, exhibited low but surprising binding affinities. This 


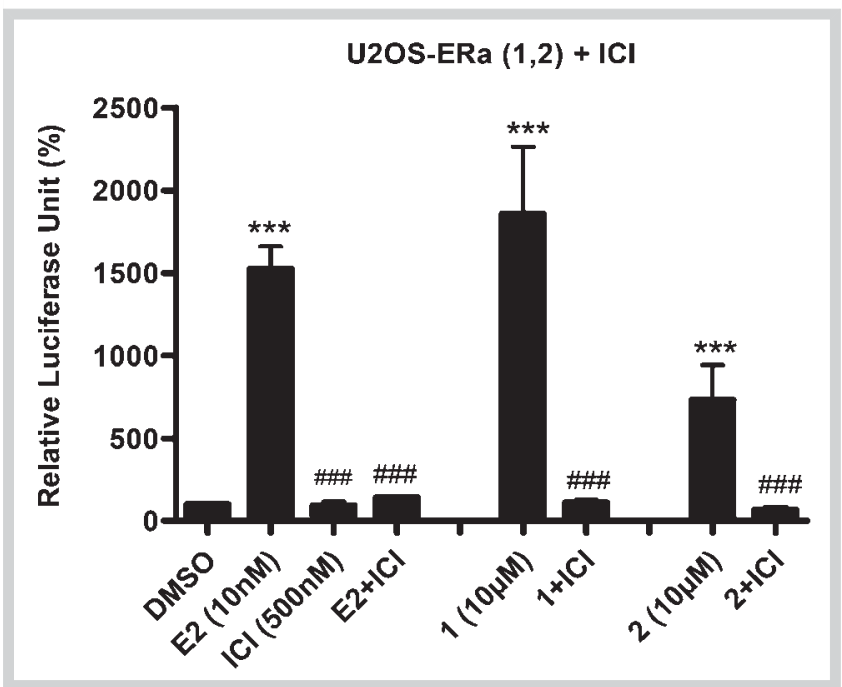

Fig. 4 Inhibition of the ER-dependent reporter gene activity of E2, 1, and 2 by Fulvestrant. Inhibition of estrogenic responses by Fulvestrant is indicative for the mediation of the effect by the ER. Significance comparing results with $0.1 \%$ DMSO $(=100 \%):{ }^{* * *} p<0.001$; significance comparing combined effects against individual treatment: ${ }^{\# \#} p<0.001$. Data represent the mean \pm SD of at least three independent, triplicate experiments.

affinity was proven to be translated into a significant activity regarding ER-dependent reporter gene expression in cells of different organs and regarding regulation of endogenous gene expression. So we considered it necessary to perform molecular docking studies in silico to further understand the interaction of erythroidines with the ER LBD on a molecular level. Our hypothesis was that the nitrogen atom existing in $\mathbf{1}$ and $\mathbf{2}$ could trigger binding to the ER. This nitrogen can be protonated and form a hydrogen bond with known important hydrophilic amino acids such as His 524, Asp353, and Arg394 inside the binding pocket of the receptor [16]. One the other hand, the nitrogen in oxo-erythoidine derivatives cannot be protonated and, thus, the binding ability is prohibited in compounds $\mathbf{3}$ and $\mathbf{4}$.
Specifically, in order to investigate the binding of compounds 1 and $\mathbf{2}$ to the ER, all possible conformations and stereochemistry patterns considering the nitrogen inversion were investigated $[17,18]$. The theoretical pKa value of each nitrogen atom was calculated as 9.26 and 9.12, respectively, using ChemAxon software (www.chemaxon.com) suggesting that at $\mathrm{pH} 7$, the nitrogen atom is protonated and each compound can exist in an $R / S$ nitrogen configuration. Additionally, calculated $\log \mathrm{D}$ values on $\mathrm{pH} 7$ were found to be -1.43 and -1.86 , respectively, showing very low lipophilicity. After 1000 runs of a conformational search using the Monte Carlo/Low Mode (MC/LMOD) algorithm, the global minimum of each compound was depicted (Fig. 14S, Supporting Information). These structures reveal that in the $S$ nitrogen configuration, the $\mathrm{NH}$ group is better exposed to the solvent or to the interaction with the receptor pocket, while in the $R$ configuration, $\mathrm{NH}$ is sheltered by the core of the molecule.

Furthermore, docking calculations were performed considering the lowest energy structure obtained for the interaction of each compound with the ER $\alpha$ LBD. Starting from the crystal structure of LBD-ER $\alpha$ in a complex with diethylstilbestrol (DES) (PDB entry 3ERD) or ortho-trifluoromethylphenylvinyl estradiol (EZT) (PDB entry 2P15), the crystallographic ligand was replaced manually by compounds 1 and 2 . Both ligands fit within the ligand binding cavity of the 3ERD LBD structure of ER $\alpha$, exhibiting only weak Van Der Waals (VdW) interactions. In the case of the 2P15 ER $\alpha$ LBD structure, the binding pocket is larger, so both ligands were suitably fitted. In both cases, the $S$ enantiomer (regarding the $\mathrm{N}+$ configuration) forms a hydrogen bond with His 524 since the $\mathrm{NH}$ is better exposed to the receptor as described above ( Fig. 6 and 7).

\section{Discussion \\ $\nabla$}

In third world countries, people depend on traditional medicine for their primary health care, which comprises medicinal plants as a fundamental element. Efficacy is mostly evidenced by the traditional use without knowing the molecular basis of the activity. Likewise, (toxic) side effects presumably often remain unnoticed. With our studies on estrogenic activities of compounds

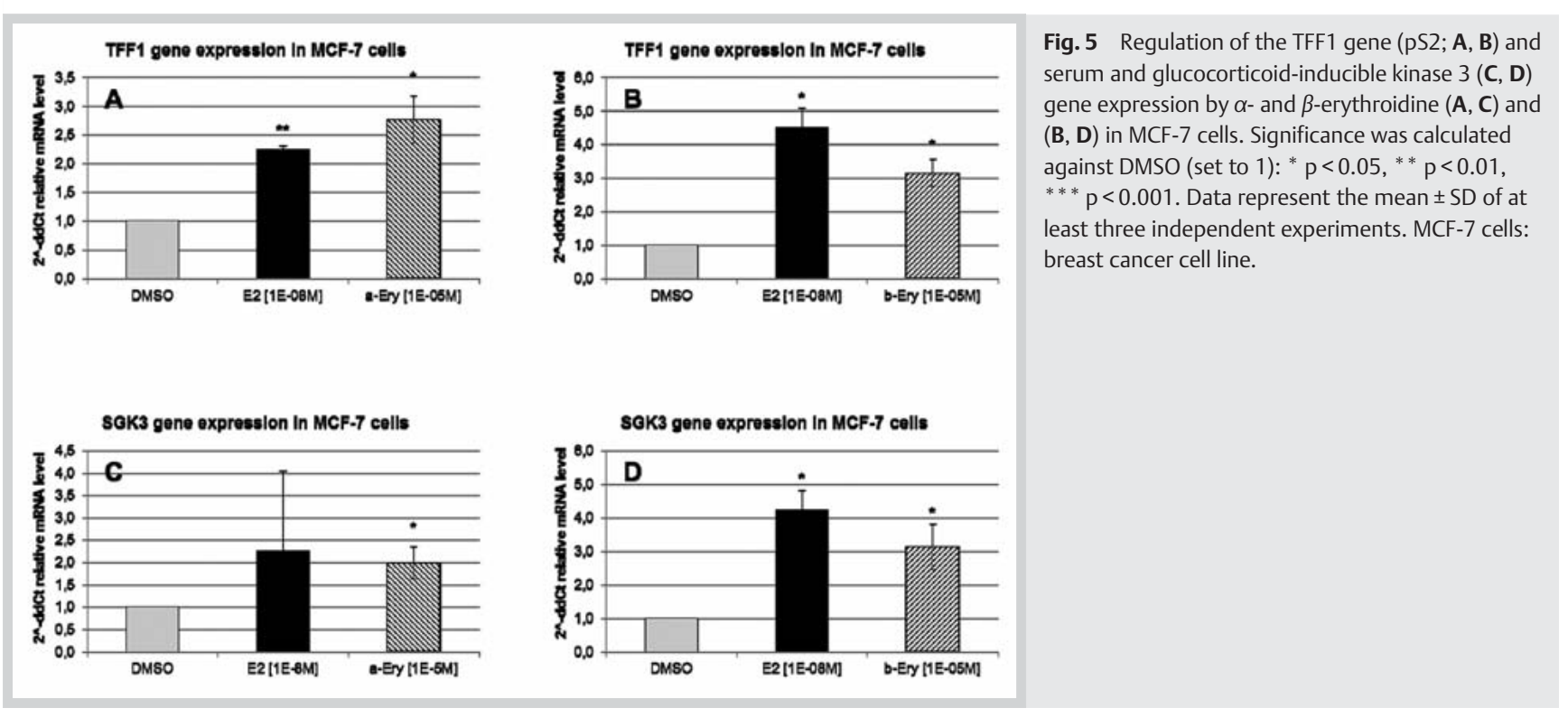



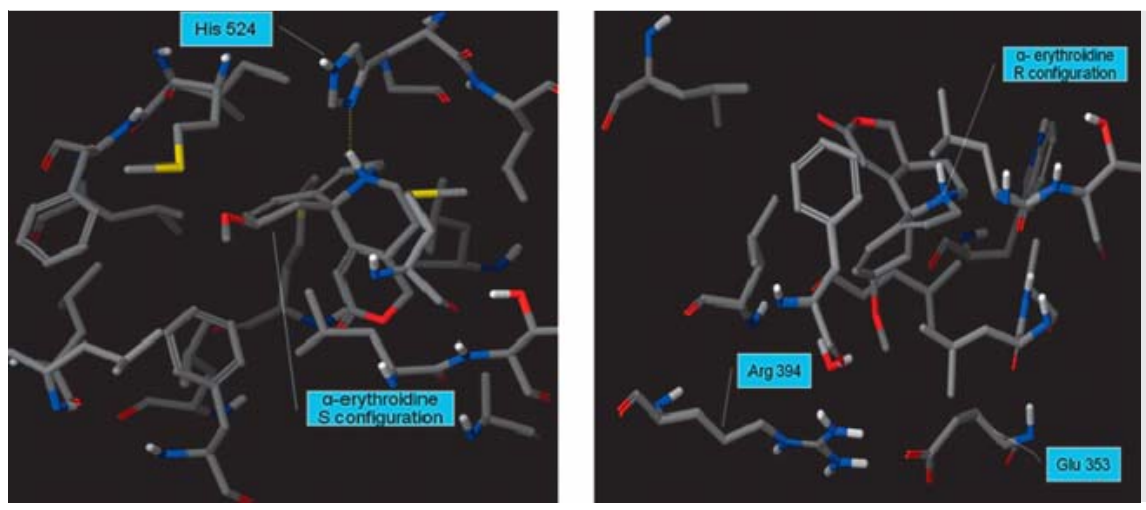

Fig. 6 Minimum energy structure of ER $\alpha$-LBD (2P15) in complex with $\alpha$-erythroidine (S configuration) (A) and $\alpha$-erythroidine ( $R$ configuration) (B). (Color figure available online only.)
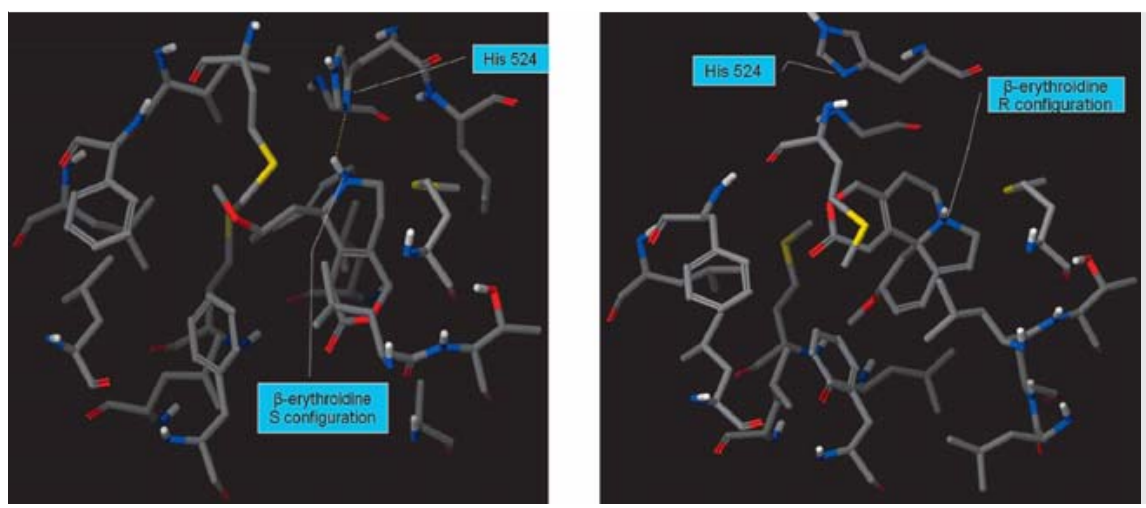

Fig. 7 Minimum energy structure of $E R \alpha-L B D$ (2P15) in a complex with $\beta$-erythroidine ( $S$ configuration) $(\mathbf{A})$ and $\beta$-erythroidine ( $R$ configuration) (B). (Color figure available online only.)

from E. poeppigiana, we aimed to contribute to the evaluation of the efficacy and safety of this medicinal plant.

Generally, plants belonging to Erythrina species are very rich in various subgroups of flavonoids. The estrogenic activity of $E$. poeppigiana could initially be linked to derivatives of the soy isoflavone genistein, which were isolated from its dichlomethane extract $[6,7]$. Nevertheless, information about the possible estrogenicity of more polar compounds of the plant, including the estrogenicity of erythroidines, was missing. Erythroidine alkaloids represent major constituents of the methanol extract in Erythrina species. Thus, the aim of the present study was to phytochemically investigate the polar constituents of the stem bark of E. poeppigiana and to evaluate their estrogenic properties using in vitro and in silico models.

Along these lines, we first characterized the relative binding affinities of the isolated erythroidines 1, 2, $\mathbf{3}$ and $\mathbf{4}$ to the ERs in comparison to $17 \beta$-estradiol. Overall, we showed that two $(\mathbf{1}, \mathbf{2})$ of the four compounds bound to ER $\alpha$ and, additionally. one of them ( 2 ) to ER $\beta$. With RBA values $\leq 0.1 \%, \alpha$ - and $\beta$-erythroidines have to be characterized as weak binders of the ERs; however, with this relative binding affinity, they are still in the range of the binding affinities of the red clover isoflavones biochanin $\mathrm{A}$ and formononetin or the endocrine disruptor bisphenol A [19]. In contrast, both oxo-derivatives, 8 -oxo- $\alpha$-erythroidine (3) and 8 -oxo- $\beta$-erythroidine (4), showed no affinity for the ERs.

Considering that the binding affinity to a receptor does not always correlate with receptor transactivation [20], the estrogenic activity of these four alkaloids was additionally assessed on cell culture models of human origin. Prior to hormonal stimulation experiments, we performed cytotoxicity assays. The MTT test did not reveal cytotoxic properties of erythroidines (Fig. 135, Supporting Information).
The initial reporter gene assays were performed in MVLN cells, ER $\alpha$-expressing MCF-7 breast cancer cell line-derived reporter cells [14]. The results exactly matched the ligand binding data, meaning measurable activity of $\mathbf{1}$ and $\mathbf{2}$ and neglectable activity of 3 and 4. This observation could also be correlated with the docking results. The oxo-erythroidine derivatives $\mathbf{3}$ and $\mathbf{4}$ have lost their ability for nitrogen protonation, so they lose their only group to form a hydrogen bond with His 524 as shown for compounds 1 and 2. Since His 524 is not so important for ER recognition compared to Arg394 and Asp353 [16], binding only to His 524 could explain the low binding affinity for compounds 1 and 2.

In order to further investigate the estrogenic activity of the two active alkaloids 1 and 2, they were assayed in the U2OS-ER $\alpha$ variant of the bone-derived human U2OS osteosarcoma cell line [15]. The rationale for this procedure stems from the observation that compounds which are structurally different from estradiol, but still exhibit estrogen-like properties, may have organ-specific functional qualities, like, for example, the synthetic estrogen receptor modulator Tamoxifen. As shown by the results in 0 Fig. 3 , $\alpha$-erythroidine (1) and $\beta$-erythroidine (2) significantly induced reporter gene activity in U2OS-ER $\alpha$ cells, with a more pronounced magnitude of stimulation for $\mathbf{1}$. The stimulation pattern of the reporter genes in 0 Fig. $\mathbf{2}$ and $\mathbf{3}$ did not result in a steadily increasing dose-response pattern. So far, we are missing a mechanistic clue, but nonlinear dose-response patterns have been extensively discussed for endocrine disrupting chemicals (for review see [21]). The pure antiestrogen Fulvestrant ${ }^{\circledR}$ completely inhibited the estrogenic activity of these alkaloids ( Fig. 4), implying that the observed effect was primarily mediated through the ER. In essence, $\alpha$ - and $\beta$-erythroidines are capable of inducing ERmediated reporter gene activity in cells originating from mam- 
mary glands and bones, thereby not exhibiting organ selective properties.

Reporter gene constructs usually contain minimal or reduced promotor element arrangements with a low number of DNA base pairs comprising the respective estrogen response element and, therefore, do not entirely mimic complex promotors of responsive genes, which often comprise several thousand base pairs. For weak estrogenic compounds, it is therefore important to test whether they are capable of triggering the ER-dependent regulation of expression of endogenous genes. We therefore investigated the impact of $\mathbf{1}$ and $\mathbf{2}$ on the regulation of expression of specific estrogen-regulated genes in MCF-7 cells, namely TFF1 and SGK3, by semiquantitative real-time PCR. TFF1, formerly known as pS2, was the gene from which an estrogen response element as a molecular switch for the ER was initially described $[22,23]$. It also represents a gene which, in the presence of estradiol, is significantly upregulated both in human MCF-7 breast cancer cells and in breast cancer biopsies of estrogen-dependent breast cancers, and, therefore, qualifies as an E2 responsive marker gene [22-24]. In our study, E2, as well as both erythroidines, induced a significant upregulation of TFF1 ( Fig. 5 A and $\mathbf{B}$ ), thus confirming their estrogenic activity, which appears to be ER-dependent because it was completely inhibited by Fulvestrant ${ }^{\circledR}$. It has been shown that E2 dose-dependently induces the expression of the SGK3 gene [25], which promotes ER-positive mammary adenocarcinoma cell survival. In the current study, E2, 1, and 2 induced an upregulation of SGK3 (ه Fig. 5C and $\mathbf{D}$ ), thus confirming the estrogenic properties of these alkaloids even on a complex promotor in a natural genomic organization. Regarding the regulation of expression of these primary estrogen response genes, $\alpha$-erythroidine seemed to be slightly more potent than $\beta$-erythroidine.

In order to decipher the molecular mechanism by which these alkaloids bind the ER, molecular docking simulations were performed starting from two distinct crystal structures of ER $\alpha$. In both structures, ER $\alpha$ adopts the so-called "agonist conformation" regarding the orientation of the C-terminal $\mathrm{H} 12$ helix. The first structure is the one derived in the complex with DES, a classical estradiol agonist, usually adopted for this type of docking calculation. In these conditions, ER $\alpha$ did not show any remarkable interaction with both erythroidine molecules. However, the crystal structure of ER $\alpha$ in the complex with $17 \beta$-estradiol (EZT) had proven that the LBD cavity can display a remarkable structure plasticity, notably on loop Asp411-Val418, in order to accommodate the bulky analog of EZT. Considering this specific conformational snapshot of the ER $\alpha$ structure, $\alpha / \beta$-erythroidines ( $\mathbf{1}$ and $\mathbf{2}$ ) could adequately fit and, more importantly, form a hydrogen bond between His 524 and the nitrogen atom (in the $S$ configuration). However, one has to consider that ER $\alpha$-LBD is lipophilic, while $\alpha / \beta$-erythroidines are protonated at a physiological $\mathrm{pH}$ exhibiting negative $\log \mathrm{D}$ values. This definitely would influence the entropic term $(\Delta S)$ of the system's free energy of binding, lowering the overall binding affinity. Overall molecular docking calculations support binding of $\alpha / \beta$-erythroidines for ER $\alpha$. As shown at - Fig. 6 and 7, the $S$ nitrogen configuration of both 1 and 2 forms a hydrogen bond with His 524 inside the receptor pocket. The resulting interactions provide evidence for the in vitro binding affinity and activity of these alkaloids toward the ER $\alpha$.

Overall, based on ER-dependent test systems including competitive binding analyses, reporter gene assays, and gene expression as well as in silico studies, we provide various pieces of evidence for the estrogenicity of $\alpha$ - and $\beta$-erythroidine, a prominent class of Erythrina species alkaloids contained in the methanol extract of the stem bark of E. poeppigiana. Thus, we suggest that $\alpha$ - and $\beta$ erythroidine alkaloids contribute to the estrogenic activity of the medicinal plant E. poeppigiana. Whether it contributes to the estrogenic properties recently shown in an experimental rat model [26] remains open. From our in vitro study, it is not possible to assess the overall contribution of the erythroidines to the total estrogenic activity of the plant or how it is relative to the less polar isoflavones $[6,7,27]$ or arylbenzofurans [28]. Overall, our results from four different in vitro test systems justify studies in animal models to better define efficacy and safety profiles of the test compounds.

In conclusion, our study presented here is important in the field of molecular endocrinology as well as in the area of alkaloid biochemistry, disclosing the existence of potentially estrogenic agents with this particular chemistry.

\section{Materials and Methods}

$\boldsymbol{\nabla}$

\section{General experimental procedures}

Analytical TLC was performed on Merck precoated silica gel 60 $\mathrm{F}_{254}$ plates. Spots were visualized by fluorescence extinction using UV light and vanillin-sulfuric acid reagent. Column chromatography was carried out using Si gel 0.04-0.06 mm (Merk). Amberlite XAD-4 resin (Rhom and Hass) was used for the preparation of the enriched fraction of the $\mathrm{MeOH}$ extract. A Thermo Finnigan HPLC system connected to a spectral system UV2000 PDA detector was employed for the profiling of the extracts, and ChromQuest 2.1 software was used for the operation of the system and data management. High-speed countercurrent chromatography was performed using fast centrifugal partition chromatography equipment $\left(\mathrm{FCPC}^{\circledR}\right.$, Kromaton) equipped with a 1000 mL rotor and a preparative pump (LabAlliance ${ }^{\circledR}$ ). 1 and 2D NMR spectra (COSY, COSYLR, HSQC-DEPT, HMBC) were recorded in deuterated chloroform $\left(\mathrm{CDCl}_{3}-\right.$ Merck) on a Bruker Avance III spectrometer (Bruker Biospin $\mathrm{GmbH}$ ) operating at $600.11 \mathrm{MHz}$ for ${ }^{1} \mathrm{H}$ and at $150.11 \mathrm{MHz}$ for ${ }^{13} \mathrm{C}$, with a $5-\mathrm{mm}$ inverse detection probe. The residual ${ }^{1} \mathrm{H}(7.26 \mathrm{ppm})$ and ${ }^{13} \mathrm{C}(77.0 \mathrm{ppm})$ signals of $\mathrm{CDCl}_{3}$ were used as an internal standard. 1 and 2D NMR experiments were performed with standard pulse programs, at room temperature

\section{Plant material}

The stem bark of E. poeppigiana was collected in November 2006 in Sancta Cruz (Bolivia), and identified by Ing. Mario Saldias Paz. A specimen was deposited in the Museo de Historia Natural, Facultad de Ciencias Agricolas de Santa Cruz-Bolivia under the voucher number USZ: 71775.

\section{Extraction, isolation, and identification}

Air-dried and pulverized bark of the plant $(1.66 \mathrm{~kg})$ was extracted at room temperature, successively with $\mathrm{CH}_{2} \mathrm{Cl}_{2}(3 \times 2 \mathrm{~L}), \mathrm{MeOH}$ $(3 \times 2 \mathrm{~L})$, and $\mathrm{H}_{2} \mathrm{O}(3 \times 2 \mathrm{~L})$, for $48 \mathrm{~h}$ per extraction. The $\mathrm{MeOH}$ extract was concentrated to give a residue $(90.5 \mathrm{~g})$ from which $50 \mathrm{~g}$ was subjected to amberlite resin XAD-4HP (Rhom and Hass) dissolved in hot water and remained for two days with controlled and smoothed shaking. After filtration, the resin was washed with $\mathrm{MeOH}(2 \mathrm{~L})$ and the eluent was concentrated to give $14.5 \mathrm{~g}$ of enriched extract. From this enriched extract, $10 \mathrm{~g}$ were subjected to FCPC-based separation using a biphasic system consisting of EtOAc/isopropanol/ $\mathrm{H}_{2} \mathrm{O}$ (ethyl acetate/isopropanol/water) 
in the proportion of $3 / 2 / 5$. The rotor speed was set at 1000 cycles/ $\mathrm{min}$ and the flow rate at $15 \mathrm{ml} / \mathrm{min}$. From this analysis, 119 fractions of $50 \mathrm{ml}$ each were collected. Fractions 63-67 were put together to provide $4.1 \mathrm{~g}$, which were further subjected to column liquid chromatography $(4.5 \mathrm{~cm} \varnothing)$ on $\mathrm{Si}$ gel $(0.015-0.04 \mathrm{~mm})$ leading to the isolation of 1 (40.0 mg) and $\mathbf{2}(60.0 \mathrm{mg})$. Fraction 19 of the last separation was subjected to preparative TLC using a dichloromethane/methanol, 95/5, solvent system, leading to the purification of compound $4(5.5 \mathrm{mg})$, while fractions $17-18$ (131.2 mg) were concentrated together and subjected to column liquid chromatography $(2.1 \mathrm{~cm} \emptyset)$ on $\mathrm{Si}$ gel $(0.015-0.04 \mathrm{~mm})$, leading to 3 ( $7.0 \mathrm{mg})$. The structural elucidation of the purified alkaloids was carried out using 1 and 2D NMR and comparison with literature data $[17,29,30]$. The isolated compounds ( Fig. 1) were identified as $\alpha$-erythroidine (1), $\beta$-erythroidine (2), and their oxo-derivatives, 8 -oxo- $\alpha$-erythroidine (3) and 8 oxo- $\beta$-erythroidine (4).

\section{Receptor binding assay}

The fluorescent derivative of E2, recombinant human ER $\alpha$, and recombinant human ER $\beta$ were purchased from Invitrogen ${ }^{\circledR}$, while EZT (purity > 98\%) was obtained from Sigma-Aldrich. The receptor binding affinities, RBA of 1-4, were assessed using a fluorescence polarization approach as previously described [31,32]. In brief, the concentration for EZT and 1-4 that inhibited the binding of fluorescent estrogen ES2 ( $1 \mathrm{nM})$ (Invitrogen $\left.{ }^{\circledR}\right)$ to isolated recombinant human $\mathrm{ER} \alpha$ or $\mathrm{ER} \beta$ (Invitrogen) by $50 \%$ (IC 50 ) was determined and used to derive the receptor binding affinity values: $\left[\mathrm{RBA}=\left(\mathrm{IC}_{50} 17 \beta\right.\right.$-estradiol $/ \mathrm{IC}_{50}$ compound $\left.) \times 100\right]$.

\section{Cells and plasmids}

U2OS cells were obtained from ATCC/Promochem. U2OS cells stably transfected with ER $\alpha$ (U2OS-ER $\alpha$ cells) and the (ERE) $)_{2}$-tk-Luc reporter plasmid were kindly provided by Dr. Luisella Toschi (Schering AG). MVLN cells, a derivative of an ER-positive MCF-7 cell line stably transfected with the vitellogenin-A2-promoter/luciferase reporter construct, were from Dr. Michel Pons (INSERM U439). ER $\alpha$-positive MCF-7 cells were from the German national center for biomedical material and resources (DSMZ).

\section{3-(4,5-Dimethylthiazol-2-YI)-2,5-diphenyltetrazolium bromide assay}

MTT was from AppliChem. The MTT test, as such, was performed as described in the literature [33], with 7500 U2OS cells per well of a 96-well plate.

\section{Reporter gene assays}

U2OS cells were routinely cultured in phenol red-free DMEM-F12 medium containing $10 \%$ fetal calf serum (FCS) and $0.5 \mathrm{mg} / \mathrm{ml}$ gentamycin (Calbiochem/VWR). Experiments were performed in phenol red-free DMEM-F12 medium containing 5\% dextrancoated charcoal (DCC) stripped FCS, and $0.5 \mathrm{mg} / \mathrm{ml}$ gentamycin. For transfection, U2OS-ER $\alpha$ cells were plated in a 24-well plate (30000 cells/well) and transfected with $100 \mathrm{ng}$ of the (ERE) $)_{2}$-tkLuc reporter plasmid using the liposomal protocol (DOTAP; Roth) and DOTAP: DNA in a ratio of $3: 1$ [15].

MVLN cells as well as MCF-7 cells were cultured in DMEM-F12 medium as previously described [14], while experiments were performed using DMEM-F12 supplemented with $1 \%$ DCC in 24well plates (80000 cells/well).

\section{Treatment with the test substances and}

\section{Iuciferase assay}

All tested substances were serially diluted in DMSO (final DMSO concentration in test well plate of $0.1 \% \mathrm{v} / \mathrm{v}$ ). All assays were performed dose-dependently, thereby specifically adapting the test substance concentration to the respective assay in order to obtain a reliable dose-response curve. Ten nM E2 was used as a positive control, while $0.1 \%$ DMSO was used as a negative control. To investigate whether the estrogenic activity of the isolated neutral alkaloids is mediated by ER activation, cells were incubated with the effective doses of the substances in the absence or presence of the pure antiestrogen Fulvestrant, also referred to as Faslodex and ICI 182780 (purity > 99\%; Tocris) at the test concentration of $500 \mathrm{nM}$ [34]. In all of the reporter gene experiments, cells were exposed to the test substances $24 \mathrm{~h}$ prior to the measurement of luciferase activity. All experiments were done in triplicate and were independently repeated three times.

RNA isolation, cDNA synthesis, and mRNA quantification using realtime PCR

After a 24-h treatment period, the total cytoplasmic ribonucleic acid (RNA) was extracted from adherent MCF-7 cells using Trizol ${ }^{\circledR}$ reagent (PeqLab) according to the manufacturer's protocol. RNA samples were qualitatively examined on a $1 \%$ agarose-formaldehyde gel. DNA contamination was enzymatically eliminated by digestion (deoxyribonuclease I, Ambion). Absence of genomic DNA was checked by PCR. M-MLV reverse transcriptase (Promega) and oligo (dT) 12-18 primers were used for the first-strand cDNA synthesis. Quantitative real-time PCR using Platinum ${ }^{\circledR}$ Taq DNA polymerase (Life Technologies) and a thermal cycler with an iQ real-time detection system (BioRad) was performed for mRNA quantification. SybrGreen I (Sigma-Aldrich) was used as a detection probe. The reactions were run three times in triplicate. After vortexing, $50 \mu \mathrm{l}$ aliquots of the total mix were pipetted to each well of the 96-well PCR plate (BioRad). PCR reactions consisted of a first denaturing cycle at $95^{\circ} \mathrm{C}$ for $3 \mathrm{~min}$, followed by 50 cycles of $10 \mathrm{~s}$ at $95^{\circ} \mathrm{C}, 15 \mathrm{~s}$ at $60^{\circ} \mathrm{C}$, and $30 \mathrm{~s}$ at $72^{\circ} \mathrm{C}$. Fluorescence was quantified at the end of the $60^{\circ} \mathrm{C}$ annealing step and product identity was confirmed by a melting curve analysis $\left(60-95^{\circ} \mathrm{C}\right)$. Primer sequences are summarized in Table 1S, Supporting Information. For all genes measured, we obtained three different biological replicates (mRNA preparations) from three independent cell culture experiments resulting in at least three independently synthesized cDNAs from independent cell culture experiments. Each cDNA was subjected to qPCR analysis in triplicate. The relative mRNA amounts of target genes TFF1/pS2 and SGK3 were calculated after normalization to an endogenous reference gene (ribosomal protein 18, RPS18). Results are expressed as the relative amount of mRNA of the gene of interest compared to the mRNA levels of the housekeeping gene hRPS18, using the $2^{-\triangle \Delta C T}$ formula [35].

\section{Molecular simulation}

All calculations were run using Macromodel 9.0 (Schrödinger, Inc.). Compounds' $\mathbf{1}$ and $\mathbf{2}$ virtual structures (both $R / S$ enantiomers regarding the $\mathrm{NH}$ group) were generated using Maestro 9.3.5 (Schrödinger, Inc.). The full search in the conformational space for each molecule was achieved using the OPLS2005 force field with an MC/LMOD search algorithm. One thousand starting conformers were produced and minimized using the TNCG algorithm ( $\mathrm{rmsG}<0.01 \mathrm{~kJ} / \mathrm{mol} \AA$ ). No solvent model was used. 
The ligand binding domains of ER $\alpha$ in the agonist conformation (PDB entries 3ERD and 2P15) were chosen as starting structures for docking calculations. On each complex, the crystallographic ligand was replaced by compound $\mathbf{1}$ or $\mathbf{2}$ ( $R / S$ enantiomers). Docking calculations were performed using a 1000 step search of the mixed MC/LMOD search algorithm as implemented in Macromodel with a ratio of 0.5 and an OPLS2005* force field. A distance-dependent dielectric "constant" of $4 \mathrm{r}$ was used. All residues within $6.0 \AA$ from the ligand were allowed to move freely, while the remaining residues were treated as "frozen atoms". After each successful run, the complex was minimized using the TNCG algorithm ( $\mathrm{rmsG}<0.01 \mathrm{~kJ} / \mathrm{mol} \AA$ ). Unique conformations were stored only if they were within the lowest $50 \mathrm{~kJ} / \mathrm{mol}$.

\section{Data presentation and statistical analysis}

All data from the receptor binding affinity are expressed as mean \pm standard deviation of at least three independent experiments. Data from luciferase reporter gene assays were obtained from three independent cell culture experiments, within which treatments were performed in triplicate. Data from real-time PCR experiments were obtained from three different cell culture experiments, RNA extractions, and cDNA syntheses. Statistical analysis included one-way analysis of variance (ANOVA) followed by Bonferroni's post hoc test in order to determine significant differences. Results are defined as significant at ${ }^{*} \mathrm{p} \leq 0.05,{ }^{* *} \mathrm{p} \leq 0.01$, and ${ }^{* * *} \mathrm{p} \leq 0.001$.

\section{Supporting information}

Competition curves of ligand binding assays and 1 and 2D NMR data of isolated compounds, an HPLC-DAD chromatogram of the methanol extract, data of the MTT test, and global minimum structures of $\alpha$ - and $\beta$-erythroidine using molecular docking simulations are available as Supporting Information.

\section{Acknowledgements}

$\nabla$

A part of this research project was supported by EU-FP7REGPOT2011 project INsPiRE (284460).

\section{Conflict of Interest}

$\nabla$

The authors declare no conflict of interest.

\section{Affiliations}

${ }^{1}$ Division of Pharmacognosy \& Natural Products Chemistry, Department of Pharmacy, University of Athens, Athens, Greece

2 Molecular Cell Physiology \& Endocrinology, Technische Universität, Dresden, Germany

${ }^{3}$ Laboratory of Animal Physiology, Department of Animal Biology and Physiology, University of Yaoundé 1, Yaounde, Cameroon

${ }^{4}$ Division of Pharmaceutical Chemistry, Department of Pharmacy, Athens, Greece

\section{References}

1 Bussmann RW. Ethnobotany of the Samburu of Mt. Nyiru, South Turkana, Kenya. J Ethnobiol Ethnomed 2006; 2: 35

2 WHO. WHO calls on African governments to formally recognize traditional medicine, 31 August 2003, Johannesburg, South Africa. Geneva: WHO; 2003

3 Magne Ndé C, Njamen D, Tanee Fomum S, Wandji J, Simpson E, Clyne C, Vollmer G. In vitro estrogenic activity of two major compounds from the stem bark of Erythrina lysistemon (Fabaceae). Eur J Pharmacol 2012; 674: 87-94
4 Kone WM, Solange KN, Dosso M. Assessing sub-Saharan Erythrina for efficacy: traditional uses, biological activities and phytochemistry. Pak J Biol Sci 2011; 14: 560-571

5 Hegde HV, Hegde GR, Kholkute SD. Herbal care for reproductive health: ethno medicobotany from Uttara Kannada district in Karnataka, India. Complement Ther Clin Pract 2007; 13: 38-45

6 Djiogue S, Halabalaki M, Alexi X, Njamen D, Fomum ZT, Alexis MN, Skaltsounis $A L$. Isoflavonoids from Erythrina peppigiana: evaluation of their binding affinity for the estrogen receptor. J Nat Prod 2009; 72: 16031607

7 Djiogue S, Njamen D, Halabalaki M, Kretzschmar G, Beyer A, Mbanya JC, Skaltsounis AL, Vollmer G. Estrogenic properties of naturally occuring prenylated isoflavones in U2OS human osteosarcoma cells: Structureactivity relationships. J Steroid Biochem Mol Biol 2010; 120: 184-191

8 Ososki AL, Kennelly EJ. Phytoestrogens: a review of the present state of research. Phytother Res 2003; 17: 845-869

$9 \mathrm{Ng}$ PC, Ho DD, $\mathrm{Ng} \mathrm{KH}$, Kong YC, Cheng KF, Stone G. Mixed estrogenic and anti-estrogenic activities of yuechukene - a bis-indole alkaloid. Eur J Pharmacol 1994; 264: 1-12

10 Nazrullaev SS, Bessonova IA, Akhmedkhodzaeva KHS. Estrogenic activity as a function of chemical structure in Haplophyllum quinoline alkaloids. Chem Nat Compd 2001; 37: 551-555

11 Allred KF, Yackley KM, Vanamala J, Allred CD. Trigonelline is a novel phytoestrogen in coffee beans. J Nutr 2009; 139: 1833-1838

12 Aguilar MI, Giral F, Espejo O. Alkaloids from the flowers of Erythrina americana. Phytochemistry 1981; 20: 2061-2062

13 Chawla AS, Redha FM, Jackson AH. Alkaloids in seeds of four Erythrina species. Phytochemistry 1985; 24: 1821-1823

14 Demirpence E, Duchesne MJ, Badia E, Gagne D, Pons M. MVLN cells: a bioluminescent MCF-7-derived cell line to study the modulation of estrogenic activity. J Steroid Biochem Mol Biol 1993; 46: 355-364

15 Möller F, Zierau O, Jandausch A, Rettenberger R, Kaszkin-Bettag M, Vollmer $G$. Subtype-specific activation of estrogen receptors by a special extract of Rheum rhaponticum $\left(\right.$ ERr $\left.731^{\mathrm{R}}\right)$, its aglycones and structurally related compounds in U2OS human osteosarcoma cells. Phytomedicine 2007; 14: 716-726

16 Lambrinidis G, Halabalaki M, Katsanou ES, Skaltsounis AL, Alexis MN, Mikros E. The estrogen receptor and polyphenols: molecular simulation studies of their interactions, a review. Environ Chem Lett 2006; 4: 159-174

17 Reimann E. Synthesis pathways to Erythrina alkaloids and Erythrina type compounds. In: Herz W, Falk H, Kirby GW, eds. Progress in the chemistry of organic natural products. Wien, New York: Springer; 2007: 1-56

18 Hanson AW. The crystal structure of dihydro- $\beta$-erythroidine hydrobromide. Acta Cryst 1963; 16: 939-942

19 Kuiper GG, Lemmen JG, Carlsson B, Corton JC, Safe SH, van der Saag PT, van der Burg B, Gustafsson JA. Interaction of estrogenic chemicals and phytoestrogens with estrogen receptor beta. Endocrinology 1998; 139: 4252-4263

20 Meyers MJ, Sun J, Carlson KE, Marriner GA, Katzenellenbogen BS, Katzenellenbogen $J A$. Estrogen receptor-beta potency-selective ligands: structure-activity relationship studies of diarylpropionitriles and their acetylene and polar analogues. J Med Chem 2001; 44: 4230-4251

21 Vandenberg LN, Colborn T, Hayes TB, Heindel JJ, Jacobs DR jr., Lee DH, Shioda T, Soto AM, vom Saal FS, Welshons WV, Zoeller RT, Myers JP. Hormones and endocrine-disrupting chemicals: low-dose effects and nonmonotonic dose responses. Endocrine Rev 2012; 33: 378-455

22 Jakowlew SB, Breathnach R, Jeltsch JM, Masiakowski P, Chambon P. Sequence of the pS2 mRNA induced by estrogen in the human breast cancer cell line MCF-7. Nucleic Acids Res 1984; 12: 2861-2877

23 Rio MC, Bellocq JP, Gairard B, Rasmussen UB, Krust A, Koehl C, Calderoli H, Schiff $V$, Renaud $R$, Chambon $P$. Specific expression of the pS2 gene in subclasses of breast cancers in comparison with expression of the estrogen and progesterone receptors and the oncogene ERBB2. Proc Natl Acad Sci U S A 1987; 84: 9243-9247

24 Kim J, Petz LN, Ziegler YS, Wood JR, Potthoff SJ, Nardulli AM. Regulation of the estrogen-responsive pS2 gene in MCF-7 breast cancer cells. J Steroid Biochem Mol Biol 2000; 74: 157-168

25 Wang Y, Zhou D, Phung S, Masri S, Smith D, Chen S. SGK3 is an estrogeninducible kinase promoting estrogen-mediated survival of breast cancer cells. Mol Endocrinol 2011; 25: 72-82

26 Njamen D, Djiogue S, Zingue S, Mvondo MA, Nkeh-Chungag B. In vivo and in vitro estrogenic activity of extracts from Erythrina poeppigiana (Fabaceae). J Complement Integr Med 2013; 10: 1-11 
27 Tanaka H, Oh-Uchi T, Etoh H, Shimizu H, Tateishi Y. Isoflavonoids from the roots of Erythrina poeppigiana. Phytochemistry 2002; 60: 789-794

28 Tanaka H, Oh-Uchi T, Etoh H, Sako M, Sato M, Fukai T, Tateishi Y. An arylbenzofuran and four isoflavonoids from the roots of Erythrina poeppigiana. Phytochemistry 2003; 63: 597-602

29 Barton DHR, Gunatilaka AL, Letcher RM, Lobo AMF, Widdowson DA. Phenol oxidation and biosynthesis. Part XXII. The alkaloids of Erythrina lysistemon, E. abyssinica, E. poeppigiana, E. fusca, and E. lithosperma; the structure of erythratidine. Chem Soc Perkin Trans I 1973; 1: 874-880

30 Tanaka H, Etoh H, Shimizu H, Oh-Uchi T, Terada Y, Tateishi Y. Erythrinan alkaloids and isoflavonoids from Erythrina poeppigiana. Planta Med 2001; 67: 871-873

31 Halabalaki M, Alexi X, Aligiannis N, Lambrinidis G, Pratsinis H, Florentin I, Mitakou S, Mikros E, Skaltsounis AL, Alexis MN. Estrogenic activity of isoflavonoids from Onobrychis ebenoides. Planta Med 2006; 72: 488493

32 Mueller SO, Simon S, Chae K, Metzler M, Korach KS. Phytoestrogens and their human metabolites show distinct agonistic and antagonistic properties on estrogen receptor alpha (ERalpha) and ERbeta in human cells. Toxicol Sci 2004; 80: 14-25

33 Mosmann T. Rapid colorimetric assay for cellular growth and survival: application to proliferation and cytotoxicity assays. J Immunol Methods 1983; 65: 55-63

34 Wakeling AE, Bowler J. Steroidal pure antiestrogens. J Endocrinol 1987; 112: R7-R10

35 Winer J, Jung CK, Shackel I, Williams PM. Development and validation of real-time quantitative reverse transcriptase-polymerase chain reaction for monitoring gene expression in cardiac myocytes in vitro. Anal Biochem 1999; 270: 41-49 